Provided for non-commercial research and education use. Not for reproduction, distribution or commercial use.

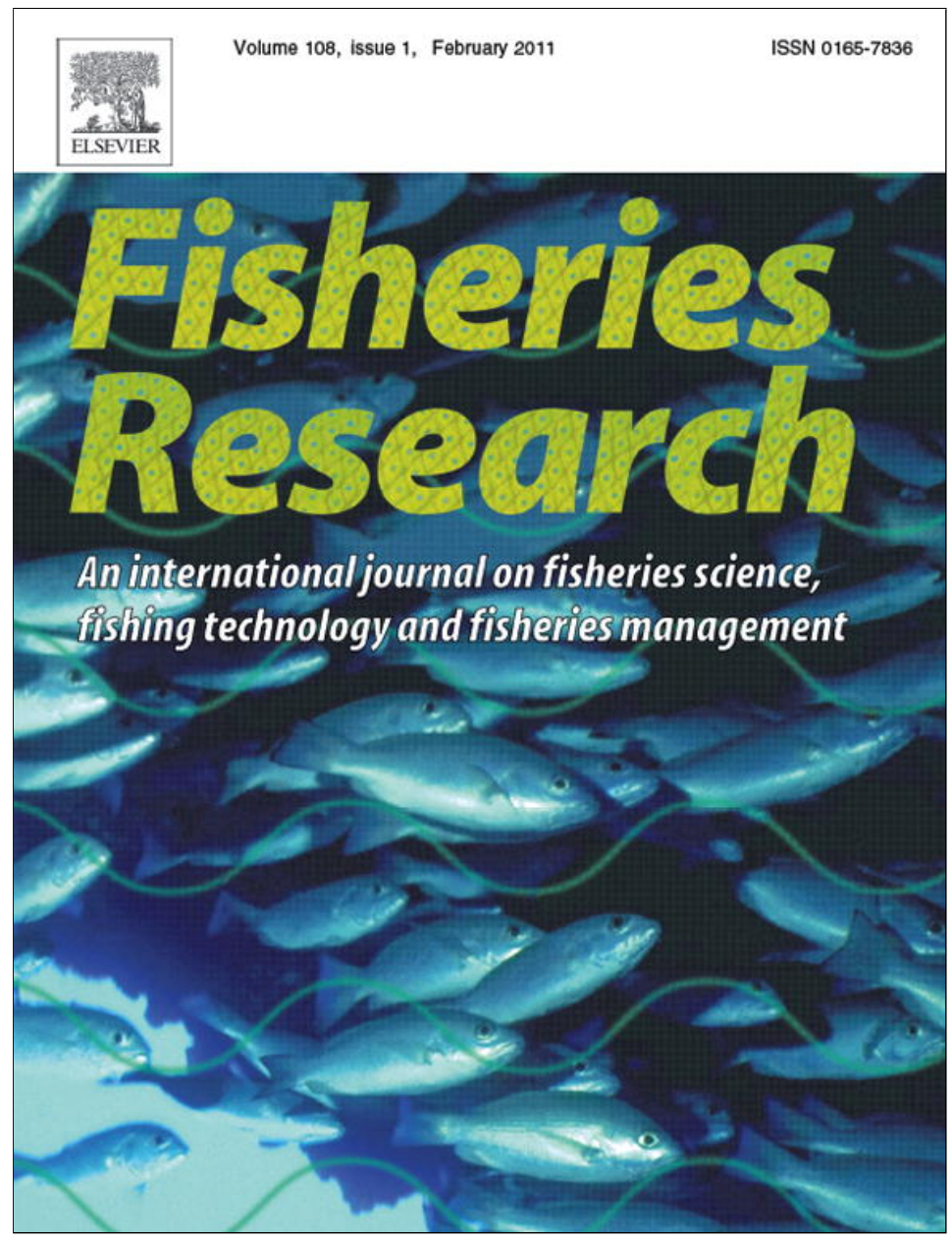

This article appeared in a journal published by Elsevier. The attached copy is furnished to the author for internal non-commercial research and education use, including for instruction at the authors institution and sharing with colleagues.

Other uses, including reproduction and distribution, or selling or licensing copies, or posting to personal, institutional or third party websites are prohibited.

In most cases authors are permitted to post their version of the article (e.g. in Word or Tex form) to their personal website or institutional repository. Authors requiring further information regarding Elsevier's archiving and manuscript policies are encouraged to visit:

http://www.elsevier.com/copyright 


\title{
A mark-recapture study of hatchery-reared juvenile European lobsters, Homarus gammarus, released at the rocky island of Helgoland (German Bight, North Sea) from 2000 to 2009
}

\author{
Isabel Schmalenbach*, Folke Mehrtens, Michael Janke, Friedrich Buchholz \\ Biologische Anstalt Helgoland, Marine Station, Alfred Wegener Institute for Polar and Marine Research, Ostkaje 1118, 27498 Helgoland, Germany
}

\section{A R T I C L E I N F O}

\section{Article history:}

Received 11 May 2010

Received in revised form

18 November 2010

Accepted 18 November 2010

\section{Keywords:}

Growth

Homarus gammarus

Hatchery-reared lobster

Mark-recapture

North Sea

\begin{abstract}
A B S T R A C T
From 2000 to 2005 about 5400 one-year-old hatchery-reared lobsters (Homarus gammarus) were tagged and released at the rocky island of Helgoland, North Sea. To date, 1-8\% of the different release cohorts were recaptured in the field and 8-19\% of these lobsters were recaptured from the semi-open area of the outer harbour. The recaptured lobsters indicated good development and growth conditions. The smallest berried females caught were $83 \mathrm{~mm}$ carapace length and 4 years old. The proportion of cultured lobsters to all measured lobsters captured around the island was 3-8\% in the years $2007-2009$. The population size of two cohorts was assessed using the Lincoln-Peterson method and the estimated survival rate averaged $30 \%$ and $40 \%$. Minimum landing size of cultured lobsters was reached after 4-7 years. Cultured lobsters showed strong fidelity to their release sites, and thus remained around the island of Helgoland. A basis has been laid to enhance this endangered lobster population by means of a large scale restocking programme.
\end{abstract}

(C) 2010 Elsevier B.V. All rights reserved.

\section{Introduction}

Both Homarus gammarus (Linnaeus, 1758) and Homarus americanus (H. Milne Edwards, 1837) have been evaluated for their potential for aquaculture and stock enhancement since the middle of the 19th century (Aiken and Waddy, 1995; Agnalt et al., 1999; Nicosia and Lavalli, 1999; Wickens and Lee, 2002; Gendron and Sainte-Marie, 2006). Bannister and Addison (1998) and Nicosia and Lavalli (1999) reviewed and summarized the literature on past and present homarid lobster culture, hatchery activities, stock enhancement programmes, and gave recommendations for the future use of lobsters. Lobster aquaculture is highly capital intensive (D'Abramo and Conklin, 1985). Several programmes aimed at enhancement of European stocks by rearing larvae in the laboratory through their planktonic stages to produce and release large numbers of small juveniles. In Norway a reduction in lobster landings was noted from about $1000 \mathrm{t}$ in 1930 s to about $50 \mathrm{t}$ during the last 20 years (Agnalt et al., 1999). Here, a large scale restocking programme was conducted with a release of 128,000 relatively small $(14 \mathrm{~mm}$ carapace length) cultured lobsters to increase recruitment (Agnalt et al., 1999; Agnalt et al., 2004). Furthermore, since 1980, substantial numbers of hatchery-reared juvenile lobsters were released in France, the United Kingdom, and Ireland. These previous release

\footnotetext{
* Corresponding author. Tel.: +49 4725 8193342; fax: +49 47258193369

E-mail address: Isabel.Schmalenbach@awi.de (I. Schmalenbach).
}

programmes on European lobster have shown that a considerable number of lobsters could be recaptured (Burton et al., 1994; Tveite and Grimsen, 1995; Bannister and Addison, 1998; Van der Meeren et al., 1998; Agnalt et al., 2004) and provided data on growth, maturity sizes, length frequencies, movement and catch per unit effort of the lobsters in their habitats.

At the German coast, the subtidal cliffs of the island of Helgoland (North Sea, German Bight) harbour a geographically and ecologically isolated small population of $H$. gammarus in an area of about $33 \mathrm{~km}^{2}$ (Ulrich et al., 2001; Triantafyllidis et al., 2005). The first record of lobster landings from commercial fishery reported a yield of around 37,000 lobsters in 1615 and 40-50,000 animals per year in 1790s. Since 1880s, commercial lobster landings were more or less continuously reported (Klimpel, 1965; Schmalenbach, 2009b, 2010; Fig. 1). Until 1930s, lobsters was a locally important resource at Helgoland, with substantial economic value with catches of up to 80,000 animals ( $38 \mathrm{t}$ ) per year (Klimpel, 1965). Since 1960 s, the population size has declined dramatically and during the last decades, the landings of lobsters fluctuated at a low level with only a few hundreds per year. The reasons for the decline in landings of the Helgoland lobsters are not known in detail, but may include habitat destruction during and after the second world-war, extensive fishing pressure in 1950s and 1960s, and anthropogenic pollution of the North Sea waters (Klimpel, 1965; Anger and Harms, 1994; Walter et al., 2008). Legislative regulations in 1981 and 1999 may have helped to prevent a complete disappearance of the local stock. These regulations include the establishment of a no-catch 

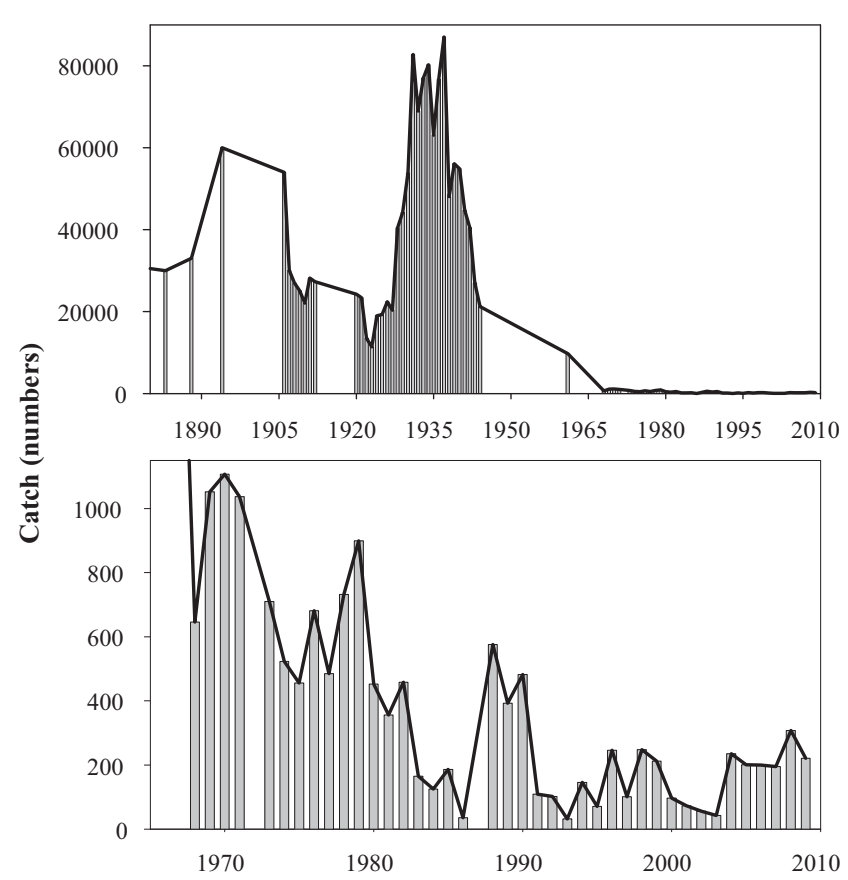

Fig. 1. Commercial landings of European lobster (Homarus gammarus) around the island of Helgoland from 1883 to 2009.

protection area, an agreement on a minimum landing size of $85 \mathrm{~mm}$ carapace length, a ban on landings of berried females, and a closed season of 1.5 months in July-August. Furthermore, since 2006 a mandatory logbook was established for fishermen to report commercial lobster landings per days and the number of lobster pots set. In years 2006-2009, the catch per unit effort increased significantly from 0.01 to 0.02 (number of lobsters per pot lift), however, with low annual catches of 200-300 lobsters per year (Schmalenbach, 2009b, 2010). However, more annual CPUE data are yet needed to estimate if the landings further increase or continue to fluctuate at a low level. Nevertheless, we suspect that these regulations to date are not sufficient to ensure the recovery of the population, which still remains below the critical threshold necessary for a recovery at a large scale. As a whole, little is known on the composition and dynamics of the Helgoland lobster population.

The Ministry of Fisheries and Agriculture of the State of Schleswig-Holstein in Germany supported a mark-recapture programme of hatchery-reared juvenile lobsters at the Marine Station on Helgoland between 1999 and 2009. The programme involved the cooperation of the local fishermen. Major long term aims were to assess the status of the local population and to lay the basis for a large scale restocking experiment (Mehrtens, 2008; Schmalenbach, 2009a). First of all, lobster rearing from local broodstock was improved (Schmalenbach et al., 2009) while juvenile lobsters were found to be released most safely and economically into the wild after they had reached a carapace length of about $15 \mathrm{~mm}$, corresponding to approximately one year of maintenance at a seasonal temperature cycle.

The objectives of the current study were to rear several thousands of juvenile lobsters, to release them to the subtidal cliffs of Helgoland, and to describe how well lobsters developed, e.g. by recording any visible signs of diseases, or if they grew their crusher claw, and finally, after which period they reached maturity and market size in the field. The study summarizes the release and recapture information, describes the movements briefly, and gives growth parameters of recaptured lobsters. The catch per unit effort of commercially landed lobsters was examined in parallel based on the logbook records of the local fishermen. The results of the study provide information to contribute further to fishery regulations and the feasibility of a large scale stock enhancement programme.

\section{Materials and methods}

The study was carried out in the years 1999-2009 at the Marine Station on Helgoland.

\subsection{Origin, rearing and tagging procedures}

Wild ovigerous female lobsters were captured by local fishermen from the rocky subtidal at Helgoland (North Sea, $54^{\circ} 11.3^{\prime} \mathrm{N}$, $7^{\circ} 54.0^{\prime} \mathrm{E}$; Fig. 2 ). The animals were placed individually into tanks $(50 \mathrm{~cm} \times 80 \mathrm{~cm}$, filled to a depth of $20 \mathrm{~cm})$ with running sea water (ca. $31 \mathrm{psu}$ ) and maintained under the seasonal temperature cycle and the natural light-dark cycle to produce larvae. The adult lobsters were fed (ad libitum) a mixture of easily accessible crustaceans and small fish. A specific plankton tank for hatching with a nylon sieve was placed under each outlet to collect newly hatched larvae. The larvae were transferred and reared in semi-flow rearing tanks (Hughes et al., 1974) at about $20^{\circ} \mathrm{C}$. The larvae were fed daily with newly hatched Artemia franciscana (Kellogg, 1906) nauplii (cysts from Sanders Brine Shrimp Company, USA) and every other day with minced crabs (whole carcasses of Cancer pagurus, Linnaeus, 1758). The larvae reached the first juvenile stage (stage IV) approximately 15 days after hatching (Schmalenbach and Franke, 2010). After moulting to stage IV the animals were placed in separate compartments and they were reared to a carapace length of about $15 \mathrm{~mm}$ using techniques described in Schmalenbach et al. (2009). This rearing specification and release size were broadly similar to those described in Burton et al. (1994) and Bannister and Addison (1998) in the UK.

Juvenile lobsters were tagged with a colour mark of Visible Implant Fluorescent Elastomer (Northwest Marine Technology Inc., Shaw Island, WA). The first mark was positioned according to a code denoting the cohort and release area of the lobsters (Table 1 ). Recaptured lobsters were re-tagged individually according to a code denoting the age, weight and carapace length (CL: measured from the eye socket to the posterior edge of the carapace) and the release area. This tag system has high tag retention and is suitable to identify lobster after more than three moults (Uglem et al., 1996; Linnane and Mercer, 1998).

\subsection{Transport, release and capture procedures}

At Helgoland, the distance between the lobster rearing facility and the release areas was short $(<4 \mathrm{~km})$ and thus facilitated handling. Juvenile lobsters were placed individually into separate cylindrical transportation bowls filled to a water level of $1 \mathrm{~cm}$. The release areas were reached in less than $1 \mathrm{~h}$ by the research vessel. There was no mortality of juveniles during transport.

About 5400 tagged hatchery-reared lobsters were released on the rocky subtidal of Helgoland during 2000-2005 (Table 1). Release onto such highly structured habitat suited the well-known shelter seeking behaviour of juvenile lobsters and is a key to ensure a successful outcome (Howard, 1988). The lobsters were released at an age of about one year (hatch date: appr. 7th July), $15 \mathrm{~mm}$ carapace length and $1.5 \mathrm{~g}$. They were released directly at the sea surface in shallow water $(\leq 10 \mathrm{~m})$ in summer at a sea temperature of $16^{\circ} \mathrm{C}$. The mean annual sea surface temperature at Helgoland was $10.7-11.6^{\circ} \mathrm{C}$ and increased from 2 to $5^{\circ} \mathrm{C}$ in February/March to about $18-20^{\circ} \mathrm{C}$ in August, and decreased thereafter (Wiltshire et al., 2008).

The released juvenile lobsters were still shelter-bound, i.e. they preferred rocky areas, where they could hide from predators in 
Table 1

The number of hatchery-reared lobsters (Homarus gammarus) released at Helgoland from 2000 to 2005, and number of first recaptures from 2001 to 2009. The sheltered outer harbour area: (1) Embankment and (2) Fog Horn, the field: (3) Institute pier, (4) Pool-Mole, (5) North-sheltered site and (6) North-exposed site.

\begin{tabular}{|c|c|c|c|c|c|}
\hline Cohort & Release year & Release area & $n$ Released & $n$ Recaptures & Recaptures/100 released \\
\hline 1999 & 2000 & $\begin{array}{l}\text { Harbour } \\
\text { (1) }\end{array}$ & 669 & 110 & 16 \\
\hline 2000 & 2001 & (1) & 367 & 69 & 19 \\
\hline 2002 & 2003 & (2) & 998 & 78 & 8 \\
\hline \multirow[t]{2}{*}{2003} & 2004 & $(1,2)$ & 1042 & 158 & 15 \\
\hline & & Field & & & \\
\hline 2000 & 2001 & (6) & 268 & 22 & 8 \\
\hline 2001 & 2002 & (5) & 601 & 7 & 1 \\
\hline 2001 & 2002 & (3) & 427 & 18 & 4 \\
\hline 2004 & 2005 & (4) & 1082 & 26 & 2 \\
\hline$n$ Total: harbour & & & 3043 & 415 & 14 \\
\hline$n$ Total: field & & & 2378 & 73 & 3 \\
\hline
\end{tabular}

crevices and where they spent most of the time in the first years (Karnofsky et al., 1989; Van der Meeren, 2000; Mehrtens et al., 2005). Van der Meeren (2000) reported that lobster loss to predators was highest after release, when the lobsters were out of shelter. Therefore, the lobsters were released in darkness to reduce loss to vision orientated fishes, e.g. shorthorn sculpin (Myoxocephalus scorpius, Linnaeus, 1758) and rock cook wrasse (Centrolabrus rupestris, Linnaeus, 1758). The juvenile lobsters were released at different areas of the rocky shore of Helgoland (Fig. 2), where the sea bed comprises a substantial scattering of boulders and cobble. The two major release areas were further subdivided, namely into the sheltered outer harbour area as a semi-open system (Embankment and Fog Horn covering an area of $9390 \mathrm{~m}^{2}$ ) and the field (Institute pier, Pool-Mole, North-sheltered site, North-exposed site). From previous dive surveys it was known that the outer harbour area corresponded to a semi-natural habitat consisting of an embankment made of natural stones. Additionally, commercial fishing is not allowed in the harbour area. The commercial fishermen captured the lobsters with lobster pots around the island of Helgoland near the release sites. The commercially landed lobsters were checked for marks, sex, size and catch location. Generally, tagged and berried lobsters were bought by the project.
Animals were captured in the release areas by the institute personnel with lobster pots, traps and scientific divers as described by Schmalenbach (2009a). Here, the number of captured lobsters was higher in the sheltered outer harbour area than around the island due to better tidal and weather conditions. Recaptured lobsters of the 1999 and 2000 cohorts were re-tagged and released back to the same capture area from 2001 to 2005.

\subsection{Recapture}

All recaptured cultured lobsters were inspected for any visible signs of diseases (Ayres and Edwards, 1982) and if they had developed a crusher claw. The development of a crusher claw is important for intra-specific competition for shelter, food, and mates, and can serve as an indicator of adequate rearing conditions in juvenile lobsters, because the stimulation of crusher claw growth is timed during the first weeks of life (Wickins, 1986; Van der Meeren and Uksnøy, 2000).

The number of released and recaptured lobsters per cohort, release year and release area is shown in Table 1 . The ratio of cultured to wild lobsters captured in the release sites of cultured lobsters was compared between the two environments (the har-
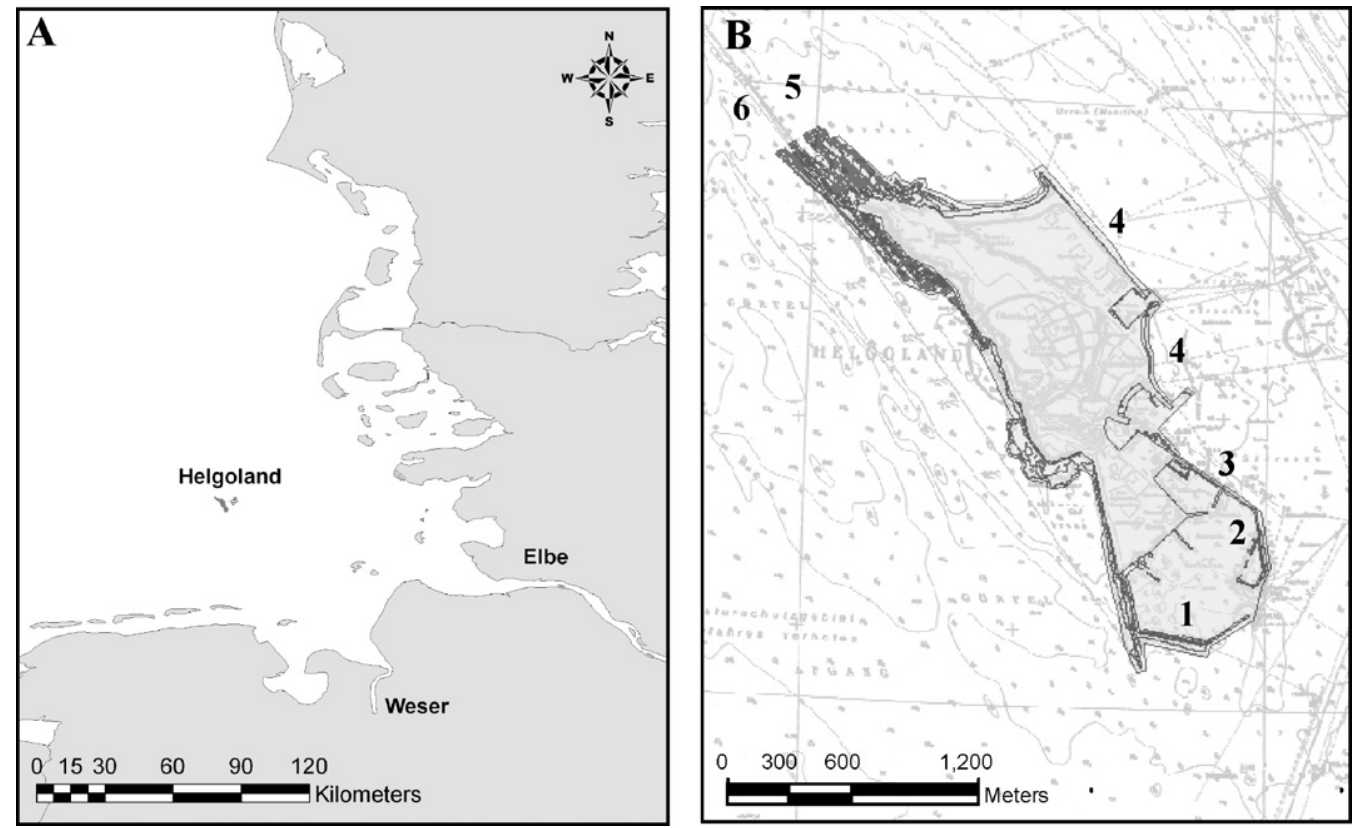

Fig. 2. (A) Location of the island of Helgoland in the German Bight, North Sea. Map: Reichert et al. (2008). (B) Release areas of hatchery-reared juvenile lobsters (Homarus gammarus) at Helgoland. The sheltered outer harbour area: (1) Embankment and (2) Fog Horn, the field: (3) Institute pier, (4) Pool-Mole, (5) 6-m-station, (6) North-sheltered site, and (6) North-exposed site. 
bour area and field). The population size and survival rate of two cohorts (1999 and 2000) released in a semi-open system (harbour area) was estimated using the multiple captures in the years 2001-2005. In the field, however, the number of multiple captures was too low for a reliable estimation of population size and survival rate of these cohorts. The abundance was estimated using the Lincoln-Petersen method, involving a single marking, and a single recapture (Seber, 1982). The estimator is based on a simple ratio and depends on the assumption that the population is closed to immigration or emigration during the sampling period and is considered a rough estimate.

$N=\left(\frac{\left(n_{1}+1\right)\left(n_{2}+1\right)}{(m+1)}\right)-1$,

here, $N$ is the Lincoln-Petersen estimate of total population size of the cohort, $n_{1}$ is the number of marked animals recaptured and rereleased into the population, $n_{2}$ is the total number of recaptures of marked animals, and $m$ is the number of multiple captures of $n_{1}$.

The $95 \%$ confidence limits for $N$ are calculated as (Hart and Gorfine, 1997)

$\operatorname{Var}(N)=\left(\frac{\left(n_{1}+1\right)\left(n_{2}+1\right)\left(n_{1}-m\right)\left(n_{2}-m\right)}{(m+1)^{2}(m+2)}\right)$

$95 \% \mathrm{CL}=N \pm 1.96 \sqrt{ } V$

Additionally, in the years 2007-2009, lobsters which were captured by the local fishermen and by the crew of the institute vessels around the island (the harbour area was not included) were recorded for marks, sex and size to calculate the proportion of cultured to wild lobsters.

\subsection{Mobility}

The mobility of 482 lobsters was related to their known release and capture areas. The shortest distance $( \pm 0.5 \mathrm{~km})$ between the known release and recapture locations was estimated with the programme ArcGIS 9.1 (ESRI). Finally, the sizes were compared between the lobsters which were captured at their original release area and the lobsters which were captured at other areas. Furthermore, the sizes were compared between the sexes. The age of lobsters at recapture averaged $4.5 \pm 1.7$ years.

\subsection{Growth}

The carapace length and weight of recaptured juveniles was measured. Their age (in years) was determined by the colour tags and was calculated from the date of mean larval hatch (7th July) to the date of recapture:

Age $=($ catch date - hatch date $) / 365$

The age at the minimum legal landing size $(85 \mathrm{~mm} \mathrm{CL})$ was determined, as well as the size and age at the onset of functional maturity of recaptured cultured female lobsters, based on the presence of eggs attached to the abdominal pleopods.

The absolute growth rates per year (AGR) (carapace length (CL) and weight $(W)$ ) for age, sexes and cohorts were used to evaluate growth according to Hopkins (1992).

$\mathrm{AGR}=($ final $\mathrm{CL} / W-$ initial $\mathrm{CL} / W) /$ time of growing

Initial mean carapace length was about $15 \mathrm{~mm}$ and weight averaged $1.5 \mathrm{~g}$.

Furthermore, the growth increment per moult was calculated for lobsters (female: $n=16$; male: $n=23$ ) released and recaptured within one year.
Growth curves from length/weight-at-age of female and male lobsters were fitted using the von Bertalanffy model (von Bertalanffy, 1938; Sparre and Venema, 1998).

$$
\begin{aligned}
& L(t)=L_{\infty}\left(1-\exp \left(-K\left(t-t_{0}\right)\right)\right. \\
& W(t)=W_{\infty}\left(1-\exp \left(-K\left(t-t_{0}\right)\right)^{b}\right.
\end{aligned}
$$

where $L(t)$ and $W(t)$ is the length and weight as a function of time $(t), L_{\infty}$ is the largest lobster, $K$ is a growth coefficient (year ${ }^{-1}$ ), and $b$ is the exponent of a length-relationship was set at 3.0. The initial condition parameter, $t_{0}$, determines the point in time when the animal has zero length. For estimation of the von Bertalanffy growth parameters $K$ and $t_{0}$ the growth equation (Eq. (5)) can be written as

$-\ln \left(1-L(t) / L_{\infty}\right)=-K t_{0}+K t$

where $t$ is the age, as the independent variable $(x)$ and the lefthand side as the dependent variable $(y)$. The equation defines a linear regression, where the slope $b=K$ and the intercept $a=-K t_{0}$, $t_{0}=-a / K$

\subsection{Statistics}

Statistical analyses were performed following Sokal and Rohlf (1995). All data sets, presented as means and standard deviations (S.D.) of replicates, were first examined for normality distribution with the Kolmogorov-Smirnov test. A one-way ANOVA followed by a Tukey's multiple comparison test at a significance level of $a=0.05$ was performed to examine variation in growth between the different cohorts using the statistical software package, Statistca 7.1 (StatSoft). T-test was applied to test the differences in the mean values of two groups using the statistical software package, SigmaStat 2.03 .

\section{Results}

\subsection{Recapture}

The recaptured lobsters showed no evidence of the "Black Spot" shell disease or other visible diseases and about $95 \%$ of lobsters had developed a crusher claw. From 2001 to 2009, 8-19\% of single year-class were recaptured from the semi-open area of the outer harbour and $1-8 \%$ were recaptured in the field around the island of Helgoland (Table 1). The ratio of cultured to wild lobsters captured in the harbour area was 1:0.3 (415 cultured and 117 wild lobsters) and in the field 1:1.1 (73 cultured and 83 wild lobsters).

The estimated population size of the 1999 and 2000 cohorts released into the outer harbour area averaged $215 \pm 48$ lobsters and $144 \pm 76$ lobsters for the years 2001-2005. If these numbers are related to the hard bottom harbour area a density of 2.3 and 1.5 lobsters $100 \mathrm{~m}^{-2}$ results. The estimated survival rate of the released cohorts was $32 \pm 7 \%$ and $39 \pm 21 \%$, respectively (Table 2 ). The proportion of cultured lobsters ( $55-165 \mathrm{~mm} \mathrm{CL}$ ) to all measured lobsters (cultured and wild lobsters) $(55-170 \mathrm{~mm} \mathrm{CL})$ captured around the island was 3.2\%, 6.3\% and 7.6\% in 2007, 2008 and 2009, respectively. The size distribution of all measured lobsters is shown in Fig. 3.

\subsection{Mobility}

Most lobsters (92\%) which were released at an age of one year remained close to their release area. These lobsters were recaptured at a mean carapace length of $77 \pm 25 \mathrm{~mm}(n=442)$ within a radius of $\geq 0.5 \mathrm{~km}$ of their original release area. The other $8 \%$ of lobsters were captured between 1 and $5 \mathrm{~km}(2.4 \pm 1.1 \mathrm{~km})$ away from their original release area with a larger significant difference $(p<0.001)$ 
Table 2

The population size $(\mathrm{N})$ and survival rate of two cohorts of hatchery-reared lobsters (Homarus gammarus) released in the harbour area at Helgoland. The abundance was estimated using the Lincoln-Petersen method. $n_{1}$, number of marked animals recaptured and re-released into the population; $n_{2}$, total number on recaptures of marked animals; $m$, number of multiple captures of $n_{1} ; N \pm 95 \%$ confidence level; S.D. = standard deviation.

\begin{tabular}{|c|c|c|c|c|c|c|}
\hline & 2001 & 2002 & 2003 & 2004 & 2005 & Mean \pm S.D. \\
\hline \multicolumn{7}{|c|}{1999 Cohort: 669 released lobsters } \\
\hline$n_{1}$ & 29 & 23 & 23 & 5 & 9 & \\
\hline$n_{2}$ & 33 & 29 & 40 & 8 & 12 & \\
\hline$m$ & 4 & 6 & 17 & 3 & 3 & \\
\hline $\mathrm{N}$ & 203 & 226 & 172 & 181 & 292 & $215 \pm 48$ \\
\hline $\pm 95 \% \mathrm{CL}$ & 138 & 53 & 9 & 5 & 18 & \\
\hline Survival (\%) & 30 & 34 & 26 & 27 & 44 & $32 \pm 7$ \\
\hline \multicolumn{7}{|c|}{2000 Cohort: 367 released lobsters } \\
\hline$n_{1}$ & - & 6 & 20 & 3 & 16 & \\
\hline$n_{2}$ & & 6 & 22 & 5 & 21 & \\
\hline$m$ & - & - & 2 & 2 & 5 & \\
\hline $\mathrm{N}$ & & & 206 & 59 & 168 & $144 \pm 76$ \\
\hline $\pm 95 \% \mathrm{CL}$ & & & 136 & 3 & 32 & \\
\hline Survival (\%) & & & 56 & 16 & 46 & $39 \pm 21$ \\
\hline
\end{tabular}

in carapace length of $95 \pm 19 \mathrm{~mm}(n=40)$ and $82 \%$ of those were male lobsters. However, there was no significant difference in size between both sexes $(p=0.299)$. Furthermore, the direction that lobsters tended to move differed between the release areas. Lobsters which were released in the northern part of the island were recaptured on the northeast and east side of the island. However, the

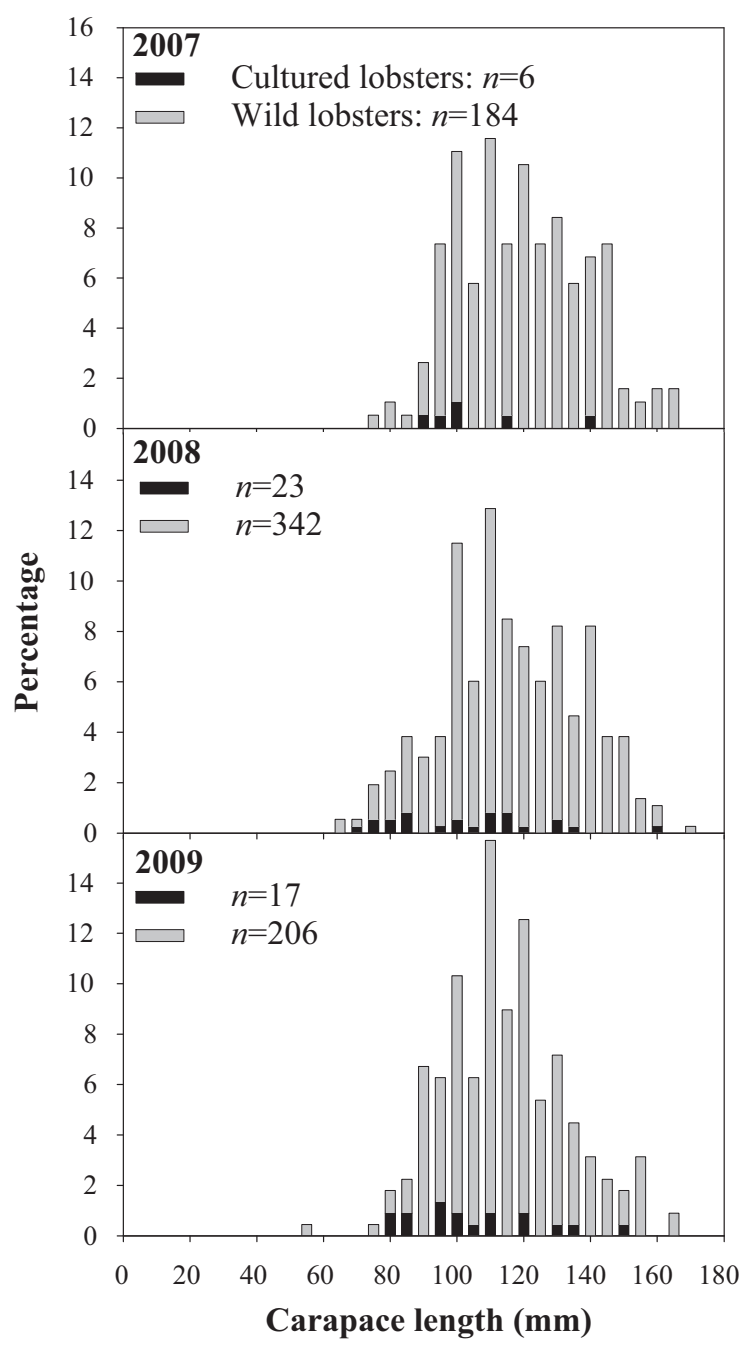

Fig. 3. Size distribution of all measured lobsters (cultured and wild lobsters) (Homarus gammarus) per $5 \mathrm{~mm}$ size class captured around the island of Helgoland. lobsters which were released in the southern part had moved in north-western and north-eastern directions. Lobsters released on the eastern part had moved in the southern direction.

\subsection{Growth}

The lobsters were recaptured at an age of 2-10 years with a carapace length of $26-118 \mathrm{~mm}$ and a weight of $14-1100 \mathrm{~g}$ for female $(n=227)$ and $28-151 \mathrm{~mm} \mathrm{CL}$ and $151-2780 \mathrm{~g}$ for male $(n=331)$ lobsters (Table 3 ). Of all recaptured cultured females, 36 animals carried eggs (16\%), indicating that lobsters had successfully mated in the wild. Legal minimum landing size $(85 \mathrm{~mm} \mathrm{CL})$ was reached after 4-7 years. There were small variations in age at legal size between and within the different cohorts. The two smallest berried lobsters were $83 \mathrm{~mm}$ CL at an age of 4.3 and 5.1 years from hatching.

The absolute annual growth rates for females ranged from about $21 \mathrm{~mm} \mathrm{CL}$ and $41 \mathrm{~g}$ at an age of 2 years to $12 \mathrm{~mm} \mathrm{CL}$ and $113 \mathrm{~g}$ at an age of 9 years and for males from $24 \mathrm{~mm} \mathrm{CL}$ and $45 \mathrm{~g}$ at an age of 2 years to $14 \mathrm{~mm} \mathrm{CL}$ and $208 \mathrm{~g}$ at an age of 9 years. There was a significant effect in growth rates per year between the different cohorts (Table 3 ). Furthermore, in females between 41 and $87 \mathrm{~mm}$ $\mathrm{CL}(44-500 \mathrm{~g})$ at an age between 2 and 6 years, average length and weight increments at moult (year ${ }^{-1}$ ) were $9 \pm 2 \mathrm{~mm}(13 \pm 3 \%)$ and $89 \pm 57 \mathrm{~g}(33 \pm 11 \%)$. In males of $46-98 \mathrm{~mm} \mathrm{CL}(57-710 \mathrm{~g})$ at an age between 2 and 7 years, increments were $12 \pm 4 \mathrm{~mm}(14 \pm 4 \%)$ and $178 \pm 120 \mathrm{~g}(35 \pm 15 \%)$.

The growth parameters per cohort were pooled and showed significant $(p<0.001)$ differences in carapace length between female and male lobsters older than 5 years, and in weight older than 3 years (Table 4). Estimated growth parameters from the von Bertalanffy equation were $K=0.3205, t_{0}=1.0521$ for females and $K=0.2265, t_{0}=0.8199$ for males. For estimation of $L_{\infty}$, we used the largest female $(118 \mathrm{~mm})$ and male $(151 \mathrm{~mm})$ lobsters. The growth curves from length-at-age and weight-at-age data for female and male lobsters are shown in Fig. 4. The estimated growth curves were similar to the measured data in Table 4 .

\section{Discussion}

\subsection{Recapture of hatchery-reared lobsters}

All recaptured lobsters were considered healthy, i.e. showed no evidence of the "Black Spot" shell disease and nearly all had developed a crusher claw. From about 5400 juvenile lobsters which were released from 2000 to $2005,8-19 \%$ of single year-class were recaptured from the semi-open area of the outer harbour and $1-8 \%$ were recaptured in the field. The return rate of $8 \%$ for a single year-class 
Table 3

Absolute growth rates per year (mean \pm S.D.) of hatchery-reared lobsters (Homarus gammarus) by cohort and sex released and recaptured at Helgoland. $n$, number of measured lobsters; CL, carapace length; $W$, weight. Different superscripts denote statistically significant differences (one-way ANOVA and paired comparisons post hoc test ( $p \leq 0.05)$ ).

\begin{tabular}{|c|c|c|c|c|c|c|c|c|}
\hline \multirow[b]{2}{*}{ Cohort } & \multicolumn{4}{|c|}{ Female } & \multicolumn{4}{|c|}{ Male } \\
\hline & $n$ & Range CL (mm) & Growth-CL (mm year $\left.{ }^{-1}\right)$ & Growth- $W\left(\right.$ g year $\left.^{-1}\right)$ & $n$ & Range $\mathrm{CL}(\mathrm{mm})$ & Growth-CL (mm year $\left.{ }^{-1}\right)$ & Growth- $W\left(\right.$ g year $\left.^{-1}\right)$ \\
\hline 1999 & 48 & $28-118$ & $16.7 \pm 3.3^{\mathrm{abc}}$ & $64.9 \pm 36.3^{\mathrm{a}}$ & 97 & $28-151$ & $18.4 \pm 4.2^{\mathrm{ab}}$ & $117.0 \pm 7.4^{\mathrm{ab}}$ \\
\hline 2000 & 52 & $30-118$ & $14.6 \pm 2.4^{\mathrm{b}}$ & $81.9 \pm 37.8^{\mathrm{b}}$ & 59 & $34-133$ & $16.8 \pm 4.3^{\mathrm{b}}$ & $114.6 \pm 9.2^{\mathrm{ac}}$ \\
\hline 2001 & 8 & $47-110$ & $18.9 \pm 4.0^{c}$ & $85.9 \pm 43.2^{\mathrm{bc}}$ & 18 & $55-115$ & $23.3 \pm 6.8^{c}$ & $135.3 \pm 19.0^{\mathrm{ad}}$ \\
\hline 2002 & 33 & $33-103$ & $19.8 \pm 6.3^{\text {de }}$ & $96.6 \pm 45.3^{\text {bd }}$ & 50 & $41-124$ & $20.4 \pm 4.0^{c}$ & $160.4 \pm 9.7^{d}$ \\
\hline 2003 & 72 & $26-100$ & $18.2 \pm 3.8^{c}$ & $95.5 \pm 38.4^{\text {bd }}$ & 95 & $38-117$ & $19.9 \pm 4.1^{\mathrm{c}}$ & $135.2 \pm 6.0^{\mathrm{ad}}$ \\
\hline 2004 & 14 & $72-98$ & $19.7 \pm 2.7^{c}$ & $120.0 \pm 28.2^{\mathrm{cd}}$ & 12 & 59-105 & $21.8 \pm 3.4^{\mathrm{c}}$ & $137.9 \pm 14.1^{\mathrm{ad}}$ \\
\hline$p$ & & & $<0.001$ & $<0.001$ & & & $<0.001$ & $<0.001$ \\
\hline
\end{tabular}

Table 4

The carapace length and weight (mean \pm S.D.) at recapture of hatchery-reared lobsters (Homarus gammarus) released at Helgoland from 2000 to 2005 (Multiple captures are included.). $n$, number of measured lobsters; $p$-values of unpaired $t$-tests comparing single pairs of means.

\begin{tabular}{|c|c|c|c|c|c|c|c|c|}
\hline \multirow[t]{2}{*}{ Age (year) } & \multicolumn{2}{|l|}{$n$} & \multicolumn{2}{|c|}{ Carapace length (mm) } & \multirow[t]{2}{*}{$p$} & \multicolumn{2}{|l|}{ Weight (g) } & \multirow[t]{2}{*}{$p$} \\
\hline & Female & Male & Female & Male & & Female & Male & \\
\hline 2 & 20 & 23 & $39 \pm 8$ & $42 \pm 6$ & 0.168 & $48 \pm 31$ & $52 \pm 21$ & 0.619 \\
\hline 3 & 57 & 63 & $54 \pm 9$ & $61 \pm 13$ & 0.793 & $117 \pm 53$ & $170 \pm 110$ & 0.001 \\
\hline 4 & 36 & 68 & $75 \pm 11$ & $79 \pm 12$ & 0.099 & $316 \pm 136$ & $376 \pm 182$ & $<0.001$ \\
\hline 5 & 52 & 78 & $83 \pm 11$ & $89 \pm 14$ & 0.010 & $428 \pm 155$ & $559 \pm 243$ & $<0.001$ \\
\hline 6 & 36 & 56 & $91 \pm 7$ & $104 \pm 10$ & $<0.001$ & $536 \pm 115$ & $855 \pm 255$ & $<0.001$ \\
\hline 7 & 15 & 14 & $99 \pm 7$ & $113 \pm 11$ & $<0.001$ & $690 \pm 132$ & $1192 \pm 426$ & $<0.001$ \\
\hline 8 & 6 & 13 & $108 \pm 6$ & $125 \pm 9$ & $<0.001$ & $863 \pm 132$ & $1531 \pm 344$ & $<0.001$ \\
\hline 9 & 4 & 10 & $110 \pm 7$ & $127 \pm 5$ & $<0.001$ & $903 \pm 135$ & $1653 \pm 218$ & $<0.001$ \\
\hline 10 & 1 & 6 & 118 & $132 \pm 11$ & - & 1100 & $1695 \pm 587$ & - \\
\hline
\end{tabular}

around the island of Helgoland is comparable to the large-scale release programme in south-western Norway (Agnalt et al., 1999). Similarly, the recapture rates of hatchery reared European lobsters in Norway and Great Britain were not higher than $8 \%$ (Burton et al., 1994; Tveite and Grimsen, 1995; Bannister and Addison, 1998; Moksness et al., 1998; Van der Meeren et al., 1998). However, releasing lobsters in the semi-enclosed outer harbour at an artificial embankment has shown that the ratio of cultured to wild lobsters can be further increased due to low immigration of wild stock and little emigration of cultured lobsters. For the two cohorts (1040 lobsters) which were released here, the population size was assessed and the survival rate was 30-40\%. At the east coast of England, the survival rate of released juvenile lobster was estimated at over $50 \%$ and this study also showed that released lobsters survived well until recruitment (Bannister et al., 1994). Furthermore, for the two cohorts released in the harbour area, the estimated density was $1.5-2.3$ cultured lobsters $100 \mathrm{~m}^{-2}$ without consideration of wild lobsters. This density corresponds to a dive assessment in the field at the Northern rocky basement of 1.5 lobsters $100 \mathrm{~m}^{-2}$ (Schmalenbach, 2009a). In contrast, Steneck and Wilson (2001) reported up to 160 American lobsters $100 \mathrm{~m}^{-2}$ off the US-Mainecoast and in northern Norway the average density ranges from 9 to 19 European lobsters per $100 \mathrm{~m}$ shoreline (Agnalt et al., 2009). However, the sampling programme will continue at Helgoland and recapture numbers may further increase.

In the field, the proportion of cultured lobsters to all measured lobsters captured reached $3.2-7.6 \%$ by releasing 2380 juvenile lobsters. In contrast, Agnalt et al. (2004) reported that the recruitment of lobsters increased substantially as a consequence of the large-scale release programme in south-western Norway. Here, commercial catches consisted of about half of cultured lobsters after having released 128,000 cultured juveniles. This indicates that releasing a high number of juvenile lobsters could further enhance a depleted lobster population.
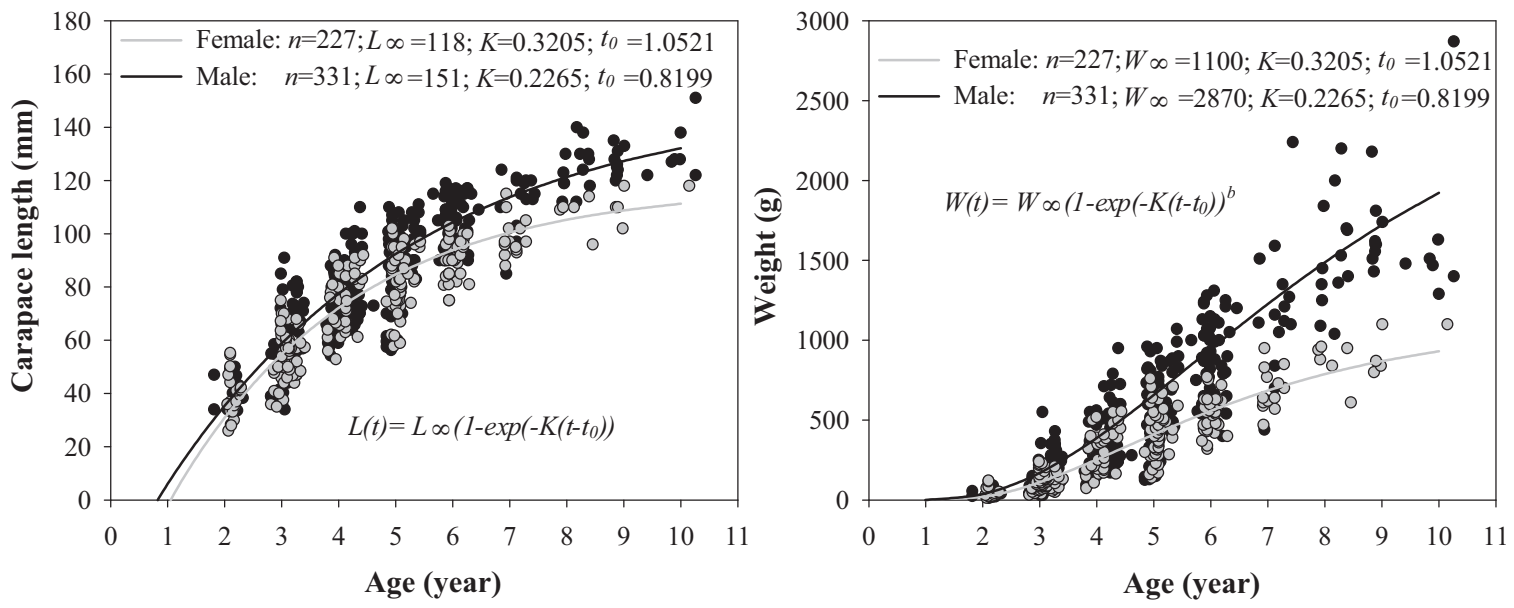

Fig. 4. Growth curves from length-at-age and weight-at-age data for female and male lobsters (Homarus gammarus) using the von Bertalanffy growth function. 
At Helgoland, nearly all cultured lobsters (92\%) were recaptured close to their original release areas. The rest was recaptured within a radius of about $2 \mathrm{~km}$ around the release areas and were significantly larger without a significant size difference between the sexes. Equally, the mark-recapture studies of Bannister et al. (1994) found that lobsters showed strong fidelity to their release sites. Furthermore, Karavanich and Atema (1998) and Karnofsky et al. (1989) reported that adult released lobsters moved only a few kilometres within their habitat, using larger boulder areas for shelter and feeding, displaying normal mating, dominance and territorial behaviour. However, in the present study, we could not determine if growing lobsters moved out of their release area at larger sizes, because the number of larger lobsters caught to date is still too small.

\subsection{Growth conditions of hatchery-reared lobsters}

In the present study, the lobsters showed significant variation in growth between several cohorts as described by Bannister and Addison (1998). The growth in male lobsters was higher than that in female lobsters which gained less weight per moult than males when sexual maturity approached. The lower growth rates in female lobsters were most probably related to ovary maturation and egg production, which requires more energy than sperm production (Templeman, 1933). A change at the size of maturity was also reported by Ennis (1972).

In the field, length and weight increments per moult in the size classes of $40-100 \mathrm{~mm}$ CL averaged about $13 \%$ in CL and $33 \%$ in weight in females and about $14 \%$ in CL and $37 \%$ in weight in males. Similar growth increments with small variation were reported in populations in England with 10.5\% for females and 12.6\% for males (Hepper, 1967), and off Scotland with $12.8 \%$ for females and $15 \%$ for males (Thomas, 1958). Comparable growth increments were also found in the American lobster (H. americanus) with $12-13.9 \%$ for females and 14.6-15.7\% for males by Ennis (1972), Conan et al. (1982), Maynard et al. (1992) and Comeau and Savoie (2001).

The estimated annual growth coefficient $K$ for cultured lobsters released as small lobsters $(15 \mathrm{~mm} \mathrm{CL})$ and recaptured after 1-9 growing years was 0.321 year $^{-1}$ for females with $L_{\infty}=118 \mathrm{~mm}$ and 0.227 year $^{-1}$ for males with $L_{\infty}=151 \mathrm{~mm}$. Similar growth parameters of the same magnitude were reported for $H$. americanus with $0.288-0.389$ year $^{-1}\left(L_{\infty}=109-99 \mathrm{~mm}\right)$ for females and 0.111-0.370 year $^{-1}\left(L_{\infty}=165-102\right)$ for males (Ennis et al., 1982; Campbell, 1983).

Lobster stock enhancement programmes in the British Isles have shown that a substantial number of released lobsters matured and reproduced in the wild (Burton et al., 1994; Wickins, 1998). At Helgoland, the minimum size at the onset of functional maturity of cultured lobsters was $83 \mathrm{~mm} \mathrm{CL}$ at an age of $4-5$ years at a mean annual sea surface temperature of $10.7-11.6^{\circ} \mathrm{C}$. Similarly, in other European lobster populations the size at maturity varied from 70 to 87 mm CL (Gibson, 1969; Lizárraga-Cubedo et al., 2003; Agnalt et al., 2006; Tully et al., 2006). Simpson (1961) and Little and Watson III (2003) suggested that sexual maturity in both Homarus species was attained at smaller sizes in warm- than in cold-water areas. Furthermore, the size of egg bearing decapods can be influenced by seasonal and local factors, such as due to population density, habitat structure, food availability, fishing pressure, or general variability in growth rates (Wenner et al., 1985; Free, 1998; Little and Watson III, 2003).

In the present study, the cultured lobsters reached the minimum landing size of $85 \mathrm{~mm}$ CL after 4-7 years. However, age at legal size varied between different cohorts by about one growing year. The minimum legal size of lobsters at Helgoland corresponded to the onset of functional maturity in females. Accordingly, the minimum legal size should be increased to safely assure that females hatch at least once before being taken out of the system, and a ban on landings of females altogether is highly recommendable. This fishing ban would increase egg production and would further enhance lobster recruitment. For other European lobster populations, Bannister et al. (1994) reported that lobsters in UK reached legal size $(85 \mathrm{~mm}$ CL) 4-5 years after release and Uglem et al. (2005) found that lobsters in Norway need 6 growing seasons to reach a legal size of $88 \mathrm{~mm} \mathrm{CL}$.

At Helgoland, growth rates throughout the lobster life cycle, as well as size at maturity and legal size were established as components of basic population parameters on a medium time scale for the first time. This therefore provides a baseline for tracking the development of the Helgoland lobster population in future studies. With the logistic support of the Institute, the initial mark-recapture programme will be continued on the basis of the tagged lobsters which are still out in the field. The data will be integrated into the ongoing long term ecological observation programmes of the benthic and pelagic biotic and abiotic environment at Helgoland (Franke et al., 2004).

Recent information on larval development and positioning (Schmalenbach and Buchholz, 2010; Schmalenbach and Franke, 2010) and the current population parameters confirm that the Helgoland population may have become sub-critical in size to sustain recruitment on a larger scale. However, some pre-requisites are encouraging: the regular growth and survival found, no further decrease during the last decades, fidelity to release sites, no diseases and rearing conditions improved (Schmalenbach et al., 2009). In addition, an ongoing quantitative fishery and dive programme will help to further assess and monitor the carrying capacity, abundance, density, reproduction potential and recruitment dynamics of the local lobster population. Already, Mehrtens (2008) and Schmalenbach (2009a) have estimated a population size of the local stock to range at about 30,000 lobsters using markrecapture experiments. The contrastingly low density found in the population at Helgoland underlines that the population is below the critical threshold for successful reproduction, and that this may explain why the population has not recovered by far to the level of 1930s (see Allee, 1950). We estimated that the rocky basement of Helgoland had carried around 1.5 million lobsters at that time. Accordingly, we estimated future release numbers at $20 \%$ of the historical level. The test of the hypothesis may be possible by following the Norwegian example to establish a restocking programme with a release of around 300,000 juveniles within five years. We expect that the recruitment rate of the enhanced stock would then significantly increase after about 10 years. If successful, the re-establishment of a self sustained lobster population could serve as an indication of a healthy environment, at least for the Helgoland ecosystem. As a next step, the feasibility of a sustainable lobster fishery may be tested. In this context, the ongoing cooperation of Helgoland fishermen is encouraging.

In summary, the island habitat is ideally suited to observe and follow a natural lobster population at close quarters on the one hand but also to use the geographically and ecologically isolated habitat around the island of Helgoland as an experimental test-bed. Given the large difference between historical and current stock levels around the island, enhancement of the local lobster population by a large scale restocking programme should proceed with little risk in terms of issues of the density-dependent carrying capacity.

\section{Acknowledgements}

The study was supported by the Ministry of Fisheries and Agriculture of the State of Schleswig-Holstein, Germany. We are particularly grateful to Dr. P. Denker and M. Momme, ALR Kiel, for their keen interest and advice in the project. Thanks are due 
to local fishermen for capture and delivery of ovigerous females. We are also grateful to many temporary hands for help to maintain larvae and juvenile lobsters, who worked as voluntaries within our project. We greatly appreciate the help of the crew of the research vessels MB "Aade" and "Diker" and the scientific diving group for capture and release of lobsters. We are also grateful to three anonymous referees and the editor for their numerous and valuable comments and suggestions.

\section{References}

Agnalt, A.-L., Kristiansen, T.S., Jørstad, K.E., 2006. Growth, reproductive cycle, and movement of berried European lobsters (Homarus gammarus) in a local stock off southwestern Norway. ICES J. Mar. Sci. 64, 288-297.

Agnalt, A.-L., Farestveit, E., Gundersen, K., Jørstad, K.E., Kristiansen, T.S., 2009. Population characteristics of the world's northernmost stocks of European lobster (Homarus gammarus) in Tysfjord and Nordfolda, northern Norway. New Zeal. J. Mar. Freshwater Res. 43, 47-57.

Agnalt, A.-L., Jørstad, K.E., Kristiansen, T.S., Nøstvold, E., Farestveit, E., Næss, H., Paulsen, O.I., Svåsand, T., 2004. Enhancing the European lobster (Homarus gammarus) stock at Kvitsøy Islands: perspectives on rebuilding Norvegian stocks. In: Leber, K.M., Kitada, S., Blankenship, H.L., Svåsand, T. (Eds.), Stock Enhancement and Sea Ranching Development, Pitfalls and Opportunities. Blackwell Publishing Ltd, Oxford, pp. 415-426.

Agnalt, A.-L., Van der Meeren, G.I., Jørstad, K.E., Næss, H., Farestveit, E., Nøstvold, E., Svåsand, T., Korsøen, E., Ydstebø, L., 1999. Stock enhancement of European lobster (Homarus gammarus): a large-scale experiment off south-western Norway (Kvitsøy). In: Howell, B., Moksness, E., Svåsand, T. (Eds.), Stock Enhancement and Sea Ranching. Fishing News Books. Blackwell Science Oxford, UK, pp. 401419.

Aiken, D.E., Waddy, S.L., 1995. Aquaculture. In: Factor, J.R.(Ed.), Biology of the Lobster Homarus americanus. Academic Press, pp. 153-175.

Allee, W.C., 1950. Principles of Animal Ecology. Saunders, Philadelphia.

Anger, K., Harms, J., 1994. The Helgoland lobster: a disappearing island population. Lobster Newslett. 7, 11-12.

Ayres, P.A., Edwards, E., 1982. Notes on the distribution of "Black Spot" shell disease in crustacean fisheries. Chem. Ecol. 1, 125-130.

Bannister, R.C.A., Addison, J.T., 1998. Enhancing lobster stocks: a review of recent European methods, results and future prospects. Bull. Mar. Sci. 62, 369-387.

Bannister, R.C.A., Addison, J.T., Lovewell, S.R.J., 1994. Growth, movement, recapture rate and survival of hatchery-reared lobsters (Homarus gammarus (Linnaeus, 1758)) released into the wild on the English east coast. Crustaceana 67, 156172.

Burton, C.A., Bannister, R.C.A., Addison, J.T., Cook, W., 1994. Lobster stock enhancement experiments II: current experiments in the British Isles. ICES CM 9, 37-40.

Campbell, A., 1983. Growth of tagged lobsters (Homarus americanus) off Port Maitland. Nova Scotia, 1948-1980. Can. Tech. Rep. Fish. Aquat. Sci. 1232, 1-10.

Comeau, M., Savoie, F., 2001. Growth increment and molt frequency of the American lobster (Homarus americanus) in the southwestern Gulf of St. Lawrence. J. Crustacean Biol. 21, 923-936.

Conan, G.Y., Robinson, D.G., Maynard, D.R., 1982. Growth at molt of lobsters in two areas of Northumberland Strait, Canada. ICES 35, 1-10.

D’Abramo, L.R., Conklin, D.E., 1985. Lobster aquaculture. In: Huner, J.V., Brown, E.E. (Eds.), Crustacean and Mollusk Aquaculture in the United States. AVI Publishing Company, Inc., Westport, Connecticut, pp. 159-201.

Ennis, G.P., 1972. Growth per moult of tagged lobsters (Homarus americanus) in Bonavista Bay, Newfoundland. J. Fish. Res. Board Can. 29, 143-148.

Ennis, G.P., Collins, P.W., Dawe, G., 1982. Fisheries and population biology of lobsters (Homarus americanus) at Comfort Cove, Newfoundland. Can. Tech. rep. Fish. Aquat. Sci. 1116, 1-45.

Franke, H.-D., Buchholz, F., Wiltshire, K.H., 2004. Ecological long-term research at Helgoland (German Bight, North Sea): retrospect and prospect-An introduction. Helgoland Mar. Res. 58, 223-229.

Free, E.K., 1998. Reproduction in the European Lobster (Homarus gammaraus (L.)). Proceedings of the Seminar at Kvitsoey 1995: the European lobster Homarus gammarus (L.). Fisk. Havet. 13, 4-26.

Gendron, L., Sainte-Marie, B., 2006. Growth of juvenile lobster Homarus americanus off the Magdalen Islands (Quebec, Canada) and projection of instar and age at commercial size. Mar. Ecol. Prog. Ser. 326, 221-233.

Gibson, F.A., 1969. Age, growth and maturity of Irish lobsters. Ir. Fish. Invest. 85, 37-44.

Hart, A.M., Gorfine, H.K., 1997. Abundance estimation of blacklip abalone (Haliotis rubra) II. A comparative evaluation of catch-effort, change-in-ratio, markrecapture and diver-survey methods. Fish. Res. 29,171-183.

Hepper, B.T., 1967. On the growth at moulting of lobsters (Homarus vulgaris) in Cornwall and Yorkshire. J. Mar. Biol. Assoc. U. K. 47, 629-643.

Hopkins, K.D., 1992. Reporting fish growth: a review of the basics. J. World Aqua. Soc. $23,173-179$

Howard, A.E., 1988. Lobster behaviour, population structure, and enhancement. Symp. Zool. Soc. Lond. 59, 355-364.

Hughes, J.T., Schleser, R.A., Tchobanoglous, G., 1974. A rearing tank for lobster larvae and other aquatic species. Prog. Fish-Cult. 36, 129-132.
Karavanich, C., Atema, J., 1998. Individual recognition and memory in lobster dominance. Anim. Behav. 56, 1553-1560.

Karnofsky, E.B., Atema, J., Elgin, R.H., 1989. Field observations of social behavior, shelter use, and foraging in the lobster, Homarus americanus. Biol. Bull. 176, 239-246.

Klimpel, J., 1965. Die neuzeitliche Entwicklung der Inselgemeinde Helgoland unter besonderer Berücksichtigung des Fremdenverkehrs. Verlagsanstalt Konstanz Konstanz.

Little, S.A., Watson III, W.H., 2003. Size at maturity of female American lobsters from an estuarine and coastal population. J. Shellfish Res. 22, 857-863.

Linnane, A., Mercer, J.P., 1998. A comparison of methods for tagging juvenile lobsters (Homarus gammarus L.) reared for stock enhancement. Aquaculture 163, 195-202.

Lizárraga-Cubedo, H.A., Tuck, I., Bailey, N., Pierce, G.J., Kinnear, J.A.M., 2003. Comparisons of size at maturity and fecundity of two Scottish populations of the European lobster, Homarus gammarus. Fish. Res. 65, 137-152.

Maynard, D.R., Savoie, F., Landsburg, W., Roach, G., Wade, E., 1992. The Cape Breton experiment on legal minimum lobster size increase: an intermediate report. CAFSAC 64, 1-47.

Mehrtens, F., 2008. Untersuchungen zu den Entwicklungsbedingungen des Europäischen Hummers (Homarus gammarus) bei Helgoland in Freiland und Labor. PhD dissertation, University of Hamburg, Germany.

Mehrtens, F., Stolpmann, M., Buchholz, F., Hagen, W., Saborowski, R., 2005. Locomotory activity and exploration behaviour of juvenile European lobsters (Homarus gammarus) in the laboratory. Mar. Freshw. Behav. Physiol. 38, 105116 .

Moksness, E., Støle, R., Van der Meeren, G., 1998. Profitability analysis of sea ranching with Atlantic Salmon (Salmo salar). Arctic charr (Salvelinus alpinus), and European lobster (Homarus gammarus) in Norway. Bull. Mar. Sci. 62, 689699.

Nicosia, F., Lavalli, K., 1999. Homarid lobster hatcheries: their history and role in research, management, and aquaculture. Mar. Fish. Rev. 61, 1-57.

Reichert, K., Buchholz, F., Bartsch, I., Kersten, T., Giménez, L., 2008. Scale-dependent patterns of variability in species assemblages of the rocky intertidal of Helgoland (German Bight, North Sea). J. Mar. Biol. Assoc. U. K. 88, 13191329 .

Schmalenbach, I., 2009a. Studies on the developmental conditions of the European lobster (Homarus gammarus Linnaeus, 1758) at the rocky island of Helgoland (German Bight, North Sea). PhD dissertation, University of Hamburg, Germany.

Schmalenbach, I., 2009b. Landings of European lobster (Homarus gammarus) and edible crab (Cancer pagurus) from 1615 to 2008, Helgoland, North Sea, Alfred Wegener Institute for Polar and Marine Research-Biological Institute Helgoland. PANGAEA 2004, http://doi.pangaea.de/10.1594/PANGAEA.727206.

Schmalenbach, I., 2010. Landings of European lobster (Homarus gammarus) and edible crab (Cancer pagurus) in 2009, Helgoland, North Sea, Alfred Wegener Institute for Polar and Marine Research-Biological Institute Helgoland. PANGAEA 2004, http://doi:10.1594/PANGAEA.733559.

Schmalenbach, I., Buchholz, F., 2010. Vertical positioning and swimming performance of lobster larvae (Homarus gammarus) in an artificial water column at Helgoland, North Sea. Mar. Biol. Res. 6, 89-99.

Schmalenbach, I., Franke, H.-D., 2010. Potential impact of climate warming on the recruitment of an economically and ecologically important species, the European lobster (Homarus gammarus) at Helgoland, North Sea. Mar. Bio. 157, 1127-1135.

Schmalenbach, I., Buchholz, F., Franke, H.-D., Saborowski, R., 2009. Improvement of rearing conditions for juvenile lobsters (Homarus gammarus) by co-culturing with juvenile isopods (Idotea emarginata). Aquaculture 289, 297-303.

Seber, G.A.F., 1982. The Estimation of Animal Abundance and Related Parameters, 2nd ed. Macmillan, New York.

Simpson, A.C., 1961. A contribution to the bionomics of the lobster (Homarus vulgaris Edw.) on the coast of North Wales. Fish. Invest. 2 (23), 1-28.

Sokal, R.R., Rohlf, F.J., 1995. Biometry. The Principles and Practice of Statistics in Biological Research, 3rd ed. WH Freeman and Co, New York.

Sparre, P., Venema, S.C., 1998. Introduction to tropical fish stock assessment. Part 1. Manual. FAO Fish. Tech. Pap. 306.1, Rev. 2. Rome, FAO, 407 pp.

Steneck, R.S., Wilson, C.J., 2001. Large-scale and long-term, spatial and temporal patterns in demography and landings of the American lobster, Homarus americanus, in Maine. Mar. Freshwater Res. 52, 1303-1319.

Templeman, W., 1933. Female lobsters handicapped in growth by spawning. Fish. Res. Board Can. Atl. Prog. Rep. 6, 5-6.

Thomas, H.J., 1958. Observations on the increase in size at moulting in the lobster (Homarus vulgaris M, Edw.). J. Mar. Biol. Ass. U. K. 37, 603-606.

Triantafyllidis, A., Apostolidis, A.P., Katsares, V., Kelly, E., Mercer, J., Hughes, M., Jørstad, K.E., Tsolou, A., Hynes, R., Triantapyllidis, C., 2005. Mitochondrial DNA variation in the European lobster (Homarus gammarus) throughout the range. Mar. Biol. 146, 223-235.

Tully, O., Bell, M., O'Leary, A., McCarthy, A., O’Donovan, V., Nee, D., 2006. The lobster (Homarus gammarus L.) fishery: analysis of the resource in 2004/2005. Fish. Resour. Ser., Bord Iascaigh Mhara (Irish Sea Fisheries Board), Dun Laoghaire, Ireland, $6,58 \mathrm{pp}$.

Tveite, S., Grimsen, S., 1995. Survival of one year old artificially raised lobsters (Homarus gammarus) released in southern Norway. ICES Mar. Sci. Symp. 199, 73-77.

Uglem, I., Belchier, M., Svåsand, T., 2005. Age determination of European lobsters (Homarus gammarus L.) by histological quantification of lipofuscin. J. Crustacean Biol. 25, 95-99. 
Uglem, I., Nœss, H., Farestveit, E., Jørstad, K.E., 1996. Tagging of juvenile lobsters (Homarus gammarus (L.)) with Visible Implant Flourescent Elastomer Tags. Aquac. Eng. 15, 499-501.

Ulrich, I., Müller, J., Schütt, C., Buchholz, F., 2001. A study of population genetics in the European lobster, Homarus gammarus (Decapoda, Nephropidae). Crustaceana $74,825-837$.

Van der Meeren, G.I., 2000. Predation on hatchery-reared lobsters released in the wild. Can. J. Fish. Aquat. Sci. 57, 1794-1803.

Van der Meeren, G.I., Uksnøy, L.E., 2000. A comparison of claw morphology an dominance between wild and cultivated male European lobster. Aquac. Int. 8 , 77-94.

Van der Meeren, G.I., Agnalt, A.L., Jørstad, K.E., 1998. Lobster (Homarus gammarus) stock enhancement in Norway, experiences from a large-scale release project from 1990-1997. In: Gendron, L. (Ed.), Can. Ind. Rep. Fish. Aquat. Sci., 244, pp. 63-68.

von Bertalanffy, L., 1938. A quantitative theory of organic growth. Hum. Biol. 10, 181-213.
Walter, I., Schmidt, M., Buchholz, F., 2008. Der Einfluss von Erdöl auf das Verhalten von Hummern. Effekte auf Nahrungssuche und Aggression. VDM Verlag Dr Müller Aktiengesellschaft \& Co. KG, Saarbruecken.

Wenner, A.M., Page, H.M., Siegel, P.R., 1985. Variation on size at onset of egg production. In: Wenner, A.M. (Ed.), Crustacean Issues 3. Factors in Adult Growth. A.A Balekema, Rotterdam, Boston, pp. 149-165.

Wickins, J.F., 1986. Stimulation of crusher claw development in cultured lobsters. Homarus gammarus (L.). Aquac. Fish. Manage. 17, 267-273.

Wickins, J.F., 1998. Lobster stock enhancement investigations 1983-1993. In: Proceedings of the Seminar at Kvitsoey 1995: the European lobster Homarus gammarus (L.). Fisken og Havet, 13, pp. 78-82.

Wickens, J.F., Lee, D.O'C., 2002. Crustacean Farming. Ranching and Culture. Blackwell Science Ltd, London.

Wiltshire, K.H. Malzahn, A.M., Wirtz, K. Greve, W., Janisch, S. Mangelsdorf, P. Manly, B.F.J., Boersma, M., 2008. Resilience of North Sea phytoplankton spring blooms dynamics: an analysis of long-term data at Helgoland Roads. Limnol. Oceanogr. 53, 1294-1302, PANGAEA 2004, http://www.pangaea.de. 